Springer Link

- Published: 18 February 2019

\title{
Determining suitability of speech-enabled examination result management system
}

- Ambrose A. Azeta,

- Sanjay Misra,

- Victor I. Azeta \&

- Victor Chukwudi Osamor

Wireless Networks volume 25, pages3657-3664 (2019)Cite this article

- Metricsdetails

\section{Abstract}

The focus of this study is to determine the suitability of speech-enabled examination result management system as a tool for checking and managing students' examination results. The theory of task-technology fit was used to identify the factors that significantly influence the use of the system. 374 verified data from students and instructors that responded to the questionnaire were analyzed and reported. The factors investigated in this study were cost, task, mobility, attitude, fitness, performance and utilization. Structural equation modeling was engaged to study the relationship between the variables and also analyze the data. The outcome of the constructed model proved that mobility, task and cost had significant influence on the fitness of the system.

This is a preview of subscription content, access via your institution.

\section{References}

1. 1. 
Khan, S., Verma, S., Agarwal, S., Krishnatrey, P., \& Sharma, S. (2015).

Voice based online examination for physically challenged. MIT

International Journal of Computer Science and Information

Technology, 5(2), 58-61.

\section{Google Scholar}

2. 2 .

Jamunkar, V., Sawankar, A. A., \& Buradkar, P. A. (2014). Voice recognition and its application in online exam for P.H people. International Journal of Research in Advent Technology, 2(2), 1-5.

\section{Google Scholar}

3. 3 .

Shanmuga, S. B., Durai, K., \& Srinivasan, S. (2014). Online examination system for blinds. International Journal of Technology Enhancements and Emerging Engineering Research, 2(5), 69-71.

\section{Google Scholar}

4. 4 .

Goodhue, D. L., \& Thompson, R. L. (1995). Task-technology fit and individual performance. MIS Quarterly, 19(2), 213-236.

\section{Article Google Scholar}

5. 5 .

Zigurs, l., \& Buckland, B. K. (1998). A theory of task-technology fit and group support system effectiveness. MIS Quarterly, 22(3), 313-334. 


\section{Article Google Scholar}

6. 6 .

McGill, T. J., \& Klobas, J. E. (2009). A task-technology fit view of learning management system impact. Journal of Computers \& Education, 52(2009), 496-508.

\section{Article Google Scholar}

7. 7 .

Dwyer, C. (2007). Task technology fit, the social technical gap, and social networking sites. In Proceedings of the thirteenth Americas conference on information systems, Keystone, Colorado, 09-12 August, 2007.

8. 8.

Alkhalifah, A., \& D'Ambra, J. (2011). Applying task-technology fit to the adoption of identity management systems. Paper presented at Australasian conference on information systems, (ACIS) 2011 proceedings, paper 31.

9. 9.

Ma, C., Chao, C., \& Cheng, B. (2013). Integrating technology acceptance model and task-technology fit into blended e-learning system. Journal of Applied Sciences, 13, 736-742.

\section{Article Google Scholar}

10.10 
Ringle, C. M., Wende, S., \& Becker, J. M. (2015). SmartPLS 3.

Boenningstedt: SmartPLS GmbH. http://www.smartpls.com. Accessed Nov 2016.

11.11.

Dijkstra, T. K., \& Henseler, J. (2015). Consistent partial least squares path modelling. MIS Quarterly, 39(2), 297-316.

\section{Article Google Scholar}

12.12.

Bagozzi, R. P., \& Yi, Y. (1988). On the evaluation of structural equation models. Journal of the Academy of Marketing Science, 16(1), 74-94.

\section{Article Google Scholar}

13.13.

Hair, J. F., Sarstedt, M., Ringle, C. M., \& Mena, J. A. (2012). An assessment of the use of partial least squares structural equation modelling in marketing research. Journal of the Academy of Marketing Science, 40(3), 414-433.

\section{Article Google Scholar}

14.14.

Hulland, J. (1999). Use of partial least squares (PLS) in strategic management research: A review of four recent studies. Strategic Management Journal, 20(2), 195-204.

\section{Article Google Scholar}


Fornell, C., \& Larcker, D. F. (1981). Evaluating structural equation models with unobservable variables and measurement error. Journal of Marketing Research, 18(1), 39-50.

\section{Article Google Scholar}

16.16 .

D'Ambra, J., Wilson, C., \& Akter, S. (2013). Application of the tasktechnology fit model to structure and evaluate the adoption of E-books by academics. Journal of the American Society for Information Science and Technology, 64(1), 48-64.

\section{Article Google Scholar}

17.17.

Dishaw, M. T., \& Strong, D. M. (1999). Extending the technology acceptance model with task-technology fit constructs. Information \& Management, 36(1), 9-21.

\section{Article Google Scholar}

18.18.

Zhu, Q., Guo, W., \& Hu, Y. (2012). Mobile learning in higher education. Students acceptance in mobile learning in three top Chinese Universities. An unpublished Bachelors thesis within Informatics Business and IT Management.

19.19. 
Staples, D. S., \& Seddon, P. (2004). Testing the technology-toperformance chain model. Journal of Organizational and End User Computing, 16(4), 17-36.

\section{Article Google Scholar}

20.20 .

NUC. (2015). National Universities Commission (NUC). List of Nigerian universities. www.nuc.edu.ng. Accessed Jan 2017.

Download references

\section{Acknowledgements}

The authors would like to thank the management of Covenant University for supporting this research. Thanks should also go to the students and instructors that responded to our questionnaire.

\section{Author information}

Affiliations

1. Covenant University, Ota, Nigeria Ambrose A. Azeta, Sanjay Misra \& Victor Chukwudi Osamor

\section{Atilim University, Ankara, Turkey} Sanjay Misra

\section{National Productivity Center, Kaduna, Nigeria}

Victor I. Azeta

Corresponding author

Correspondence to Ambrose A. Azeta.

\section{Additional information}

Publisher's Note 
Springer Nature remains neutral with regard to jurisdictional claims in published maps and institutional affiliations.

\section{Rights and permissions}

Reprints and Permissions

\section{About this article}

Cite this article

Azeta, A.A., Misra, S., Azeta, V.I. et al. Determining suitability of speech-

enabled examination result management system. Wireless Netw 25, 3657-

3664 (2019). https://doi.org/10.1007/s11276-019-01960-5

Download citation

- Published18 February 2019

- Issue Date01 August 2019

- DOlhttps://doi.org/10.1007/s11276-019-01960-5

Keywords

Instant access to the full article PDF.

\section{$34,95 €$}

Tax calculation will be finalised during checkout.

Buy article PDF

Subscribe to journal

Immediate online access to all issues from 2019. Subscription will auto renew annually.

\section{$73,83 €$}

Tax calculation will be finalised during checkout.

Buy joumal subscription

Rent this article via DeepDyve.

Learn more about Institutional subscriptions 
- Sections

- Figures

- References

Springer Nature

(C) 2021 Springer Nature Switzerland AG. Part of Springer Nature. 